\title{
The Emergence and Evolution of Palestinian Nationalism
}

\author{
Anis Salem Zaki \\ Centre for Policy Research and International Studies, Universiti Sains Malaysia, Malaysia \\ S_ahmad@usm.my
}

\section{Abstract}

The study analyses lon the questions of the interrelation between religion and nationality relate to the interpretations of justice vis-a-vis the Palestinian predicament. The paper studies the 'visions of peace' and the 'visions of citizenship' articulated by groups as diverse as Peace for Human Rights. By drawing on recent scholarship which attempted to link 'peace' and 'justice' in a meaningful way, this work devises a set of dynamic criteria with which to evaluate each peace platform and its respective interpretation of justice. Challenging the modernist-secularist inclination to interpret 'nationalism' as a 'religion surrogate' or a structural analogue of religion, the underpinning theoretical point is that religion and nationalism are intricately related and thus cannot be viewed as dichotomous or antithetical. Hence, religious sources, vocabularies, institutions and leadership may function centrally in devising interpretations of culturally embedded secularity in zones of ethnonational contestations -a process which is referred to in this dissertation as the hermeneutics of citizenship. As a conclusion, a separate Palestinian nationalism took place chiefly to cater to the Zionism issue.

Keyword: Religious; Nationalism; Palestinian Nationalism

\section{Introduction}

There was hardly any homogeneity present in the Palestinian society back in the 19th century. The rural population consisted of more than the eighty percent of the total population. The living styles were typically the traditional ones where the peasants lived in their ancestral villages, which comprised of a couple of extended families. The element of identity was chiefly a matter judged by religious and village affiliation; there was no singularity with respect to a Palestinian identity (Ghanem, 2001). Most of the land that was fertile present in the Valley of Jezreel along the coastal plain was not cultivated back in the 19th century. This was mainly due to the Bedouin depredations. Its cultivation began only after the Bedouin were driven out by the Ottomans in the early 1870s. The four holy cities of Judaism comprised mostly of the Jewish community. These cities included Hebron, Tiberias, Safad and Jerusalem. The land comprised of very few Jews, which was mainly in the fertile lowlands present in the Valley of Jezree (Khalidi, 2006). After the Bedouin problem came under control, the aforementioned areas started to be populated by the Arab people (Muslih, 1990). A lot of people who supported Zionism, thought that Palestine was sparsely 
populated and empty in the beginning of the Zionist movement. As much as this was not true, many leaders of this movement manipulated this idea. In his essay 'Truth from the Land of Palestine', Ahad HaAm wrote that it was generally perceived that Eretz Israel was desolate, which is not true in the present time, and that it was possible for anyone to buy as much land as one wanted. This was however, not true. There are hardly any unsowed fields in the country. One can only find stony mountains and sand dunes which are not worth growing anything on except for fruit trees (Khalidi, 2010).

\section{Discussion}

The nationalist movements started to rise in the late 80 s and the early 90 s where the number of nation states kept increasing; it was quite inevitable that Palestinians' travelling toward a nationalistic path would rise, yet not mainly a Palestinian one.

\section{Ottoman Period}

There were twenty generations that lived in the Ottoman state over a period of four centuries. There have been little development and evolution of ideology and mentality in Palestine, with respect to stability and peace. The situation was quite shocking in World War I and by the Zionist movement. Before the world war broke, various factors were the reason for the Arab population to create territorial identification. People had attached a religious stigma to Palestine that was shared by Jews, Muslims and Christians. Such an ideology was perceived in sacred entities, and not with political causes. Besides this, the Ottoman administrative boundaries were another factor, yet it was not as influential as the religious stigma that was attached to it (Xypolia, 2011). The aim and goals of the European powers was basically the element for the Arab since they were keen to improve their powerful position and have their defense in the European imperialism. Besides, many people had this sentimental attachment to the land as their home as they had lived for generations after generations (Khalidi, 2006).

According to Rashid Khalidi, an Arab historian, such elements of sentiments and attachment that people have for Palestine dates back before the start of the Zionism encounter. Regardless, every religious group holds sentimental closeness to places; however, nationalism ends up changing into political segmentation (Gelvin). The argument of Palestine being a separate identity had already emerged, but there was little national consciousness besides the Ottoman Empire which was not present in the beginning. There are three major threads according to historians that stand opposing the Zionism with respect to the Ottoman days: Local patriotism, Arab nationalism and Ottoman loyalism. Most of the Arab elite possessed Ottoman loyalism; they had objections with respect to Zionism as they perceived it as a nationalistic movement with the motive to create a separation between the Ottoman state and Palestine. Hence, Ottoman loyalism was the root cause of the local patriotism that grew. Zionism was seen as a threat to Palestine (Kimmerling, 1999; Leighton, 2008).

The Ottoman government failed to stop the Zionist immigration and its people settling down. This Ottoman loyalism later transformed into Ottoman opposition (Mandel). The focus of the older Palestinian generation and the ones who were political elites, was on the struggle of 
Palestine with respect to Zionism. With the rise of the Zionist immigration, the cause of Arab nationalism in the perception of the younger Palestinian generation, changed into believing that this would help in the prevention of the Zionist entity into the country (Muslih, 1990). The Jewish immigration was resisted by the Palestine Arabs. They also did not like the land purchasing by the Jews. Evidence dates back to 1891, when the Arab communities' head had sent petitions against it to the Ottoman government. The same year, on 24th June, it was reported that the Jerusalem notables had sent a letter to the vizier stating that the Jewish immigration should be stopped and that purchasing of the land should be prohibited (Muslih). Besides this, there was another letter that was a reaction to Zionism. This letter was delivered in 1899 to Theodor Herzl and was by YusifDiya' al-din Pasha al-Khalidi. The letter was a warning stating that the Zionism aspirations would be resisted by the Palestinians (Ibid). However, there was little success on the Arab Palestinian's part in resisting the subjective movement. There was a dominant threat from the Jews migrating and taking over lands as farmers. There was however, a dominant evidence of material benefit as well that the country gained from the immigration. There were new energy sources in the country, more capital and the value of land appreciated significantly (Morris, 2004). Many of the Palestinian Arabs took themselves as Ottoman subjects, before the First World War broke. They had strong opposition and differences for the Zionism act. In the First World War, these Palestinian Arabs supported the Ottoman regime and were loyal to it. However, after this identity broke down in the war, the Arabs of Palestine had little left as a peculiar identification for themselves. After the Ottoman Empire collapsed, two different ideologies took birth politically: the stronger pull of the local nationalism and the push of the Arab nationalism.

\section{World War 1: 1948}

The Arab nationalism was adopted by some Palestinian Arabs. The idea that Arab nationalism held was that all the Arabs had a singular nation since they had the same ethnicity, language and had same culture and history. The other inhabitants on the other hand, saw themselves as Syrians. This was discussed in a very important newspaper Suriya alJruwbiyy (Gelvin, 2009). The editors were 'Arifal-'Arifwere and Muhammad Hassan alBudayri. Many Palestinian, especially the elite Arab, there was a close association between Arab nationalism and local nationalism. The fact that they were committed to see their country as a part of southern Syria pointed out toward Arab nationalism. They had assumed that the modern day countries of Syria like Jordan, Israel and Lebanon would continue to be a part of the state run by Amir Faysel (Khalidi).

In 1919, at the Arab Congress, a resolution was adopted by the delegates who said that Palestine was Syria's part. According to the first resolution, the delegates consider Palestine a part of Arab Syria and they say that it always had been this way. They associate their relation on the grounds of religious, national, moral, linguistic, geographic and economic singularity (Muslih, 1990). The Syrian independence ended when Damascus was invaded by French troops in 1920; this gave the Arab nationalism a hard blow. The thirty years of British Mandate saw Palestinians in a losing position against Great Britain and the Zionist movement. Many Iraqis, Lebanese, Egyptians and Syrians grew a sense of loyalty with respect to nation-state nationalism. The problem was that the Palestinians had to overcome their shortcomings in terms of power and growth against the Zionist movement. This Zionist challenge somehow helped define the Palestinian national identity (Khalidi, 2010). Gradually in 1948, suspicion and disunity started to grow among the Arab 
states. The root cause of this was the collusion that took place between the Jewish agency and Transjordan's King Abdullah, to discuss the division of Palestine between the two. This was kept secret and was done with the aim to prevent any kind of a separate state for Palestine. These plans were highly criticized by Syria and Egypt. The Arab states were exploiting the Palestine issue which further caused disruption in the Arab unity in 1948's war. The predicaments of 1948 cause solidification of the Palestine identity.

\section{$1948-1967$}

The Palestinians had to suffer a lot after the tragic events that took place during 1947-1949. Their loss was in terms of their status of majority, their homes, and their hopes of being the rule over the country, and all the property and land. These years are often referred to as the 'lost years' by historians as Palestinians lost their role from the political map and as an independent identity (Khalidi). Besides, we can explain this hiatus also observing the fact that because of the 1948's catastrophe, Palestine was devastated. Moreover, the Pan-Arab ideology was not clear and the idea of two different identities was subsumed. Around 200,000 Arab Palestinian continues to live in the new Israel state after the 1948 war. They were given a confined Israeli citizenship and they were not associated to any kind of Palestine identity (Kaldor, Macginty, \& Wallenstein, 2007; Murakami, 1994). Jordanian citizens became the largest singular group in Palestine. However, they had no political empowerment. Other Palestinians in Syria, Gaza and Lebanon were deprived of any political identity and they may have to face barriers. This did not stop them though. In their refugee camps, schools and workplaces, the Palestinians gathered after 1948, and this marked the starting of another generation of their nationalistic identity and movements (Park \& Eldridge, 2010; Harkabi, 1990). This came out in open during the 1960s. None of the old Palestinian elite was included in this group and this movement. This class was not seen anywhere in the political place. It had suffered heavily in terms of businesses, properties and its political role. At the start, the young Palestinians found the Pan-Arabism idea appealing, as it was obvious that Arab nationalism used to be a significant part of the Palestinian identity for years. Besides, they were also lured into believing that they would receive some help from the Israeli foe that was stronger than they were (Shaul, 2000).

The leading Palestinian movement was the Movement of Arab Nationalists (MAN). There were however, other Pan-Arab groups too that included many Palestinians. Examples include the Syrian National Party and Ba'th. A Greek Orthodox named George Habash founded MAN, who was a medical student at the American University of Beirut in 1950s. The essence of MAN was Arab nationalism. However, since most of the members were Palestinian Arabs, the identity of the movement included a Palestinian essence into over ruling the Arab identity. The emphasis on Palestine differentiated MAN from Ba'ath, which was comparatively larger than MAN (Gelvin, 2009). Revenge was the strategy MAN followed to defeat Zionism and the Israel State. According to them, this battle would be of the whole Arab, having refugees as 'vanguard of the Arab nation'. They believed in sheer unity in order to be successful. Gamal Abdel Nasser, Egypt's leader was accepted by MAN in 1955. He was seen as the only person who could unite the Arab nation with respect to the subjective struggle. After this embrace, MAN's movement started to drift further and away from what the original purpose was. MAN had to face more and more competition in 1960s by new Palestinian organizations. 
One example of such group is Fatah. This movement was founded by Yasser Arafat with his friends at Cairo University. It was founded as the Movement for the Liberation of Palestine in 1950s. The name Fatah is derived from 'harakat al-tahrir al-filastini'. Fatah's ideology was quite different than that of MAN. MAN believed in Arab unity in order to liberate Palestine. The former however, believed in Palestine liberation to form Arab unity (Baumgarten, 2000). A Palestinian nationalist ideology was proposed by Fatah, where Palestine was to be liberated and giving matters into the hands of the Palestinian refugees. Fatah's most significant ideology was using armed struggle. It aimed at motivating the Palestinian refugees into aggressive and determined people to fight for national liberation (Ibid).

\section{Arabs in the Occupied Territories}

There are roughly 3.5 mil Palestinians are residing in the particular filled areas from the West Bank and the Gaza Strip (Gelvin, 2009). Of the roughly two. 5 mil Palestinians residing in the particular West Bank, concerning 300, 000 usually are NOT registered refugees. Many of the Palestinians residing in the particular West Bank can track their particular ancestry pertaining to many years. This Gaza Strip is one of the nearly all densely used regions in the world, having in excess of 1 mil persons, as well as the majority is NOT registered refugees. Though lots of the citizens inside West Bank along with a vast majority inside Gaza Strip usually are refugees, Palestinian nationalism developed in another way underneath Israeli military job. At first, Palestinian nationwide identification seemed to be slower to create inside filled areas, specifically the particular West Bank, as compared to inside refugee camps. There was a general hope inside West Bank that the region will go back to help Michael Jordan. This Gaza Strip seemed to be filled by means of Egypt by 1949 until finally 1967. Soon after 1967, the particular West Bank plus the Gaza Strip had been underneath Israeli military job with the subsequent thirty-eight several years until finally 2005 (Reuveny, 2003).

This Israeli got carried out a unilateral disengagement prepare from the Gaza Strip within September connected with 2005. Most Israeli funds inside Gaza Strip as well as several inside West Bank had been taken apart, having removing all 9, 000 Israeli settlers. These days, the particular Palestinian Guru as well as Israel have shared management in the West Bank. Israel preserves entire manage connected with Israeli funds, highways, drinking water, airspace, external safety measures, as well as is bordered by for the whole place. With 1994, the particular Palestinian Guru needed in excess of administrative expert inside Gaza Strip, good phrases from the Oslo Accords. Soon after complete Israeli disengagement connected with Israeli settlers as well as military within September connected with 2005, the particular Palestinian Guru got complete administrative expert inside Gaza Strip, although Israel even now controlled is bordered by, airspace, as well as territorial marine environments. Edges are a dilemma pertaining to the Palestinians (Meyer \& Neyer, 1995). The feeling for that Palestinian with a boundary, a great airport, or even a checkpoint reinforces their own Palestinian identity. With obstacles, every single Palestinian is encountered with the likelihood regarding pestering as well as different. The occupants on the Gaza Strip must have a minimum of about three diverse identity files to get free from this Gaza Strip as well as directly into Israel, or elsewhere, considering that just about all use of as well as through the Gaza Strip is by means of Israel. Simply a fortuitous few, a lot less than $10 \%$, own just about all about three of the identity files. For other human population, this Gaza Strip is their own the penitentiary, 
ornamented on just about all features by means of closely protected barbed cord walls together with only one leave (Khalidi, 2006). The Allenby Bridge is the main avenue of entry between Jordan and the West Bank. This Palestinians which traveling back and forth possess routinely already been suffering from the national boundaries bridging that will more than double the size of this journey. Regarding Palestinians vacationing through the Bill Gurion airport terminal, this penetration generally consists of a prolonged interrogation and lookup method by plainclothes security officials upon appearance, plus a similar yet often extended procedure with departure (Ibid). It really is with these kind of is bordered by and also obstacles that will Palestinians are usually designated for unique therapy and therefore are purposely reminded of their Palestinian identification. In an appointment, any Fateh activist voiced the aggravations, "to use a talk about, any territory and also passport to endure, because they end the actual Palestinians almost everywhere. To possess a land. To obtain normal water, any homeland, every single child moves almost everywhere. And become related to someplace, but not at all times becoming kicked out of everywhere" (Schulz, 1999). Within the occupied territories, the Palestinians' close contact the ground with the Israeli armed service and also regulators influenced their own approach involving resistance and also their own political prospect. Armed resistance has been seen as a lifeless stop mainly because Palestinians might certainly not really challenge the seriously network. And also inspired Israeli armed services, which they noticed every day. Fateh's call for armed struggle resonated while using the Palestinian refugees throughout exile, however, in the occupied territories, many Palestinians opted for approach involving steadfastness, Samed throughout Arabic (Donna, 1997).

The particular peasant exactly who stayed put on his area and refused in order to leave symbolized continuity and connection with the land, although Israel wouldn't ensure it is feasible for those people Palestinians exactly who chose to stay. The particular Israelis constructed a network of high-speed tracks bypassing Palestinian areas for connecting Jewish settlements with one another sufficient reason for Israel right. Palestinians were not permitted to journey in most of these roads. Palestinians ended up commonly denied creating will allow, however, when terrain stayed bored untended for several years it could be confiscated. In the area of production, Israel utilized prohibitions in addition to obstructive restrictions like capping the Palestinian use of farming, drinking water at the 1967 amount, environment restricts in farming manufacturing, in addition to necessitating any make it possible for to replace or even change any fruit tree (Benedict, 1991).

The Gaza Strip has a lack of basic natural resources and employment opportunities and is more destitute than the West Bank. As the years passed, the disillusioned and frustrated younger generation in the strip, who grew up with the occupation and for whom military repression had become commonplace, no longer feared the Israeli army and authorities and were more likely to use armed resistance. Their growing sense of despair exploded on December 9, 1987 in reaction to the incident in which an Israeli truck driver hit a car and killed four Palestinians in Gaza. Riots and demonstrations broke out all across the occupied territories. The intifada released tensions and created greater cohesion between the West Bank and the Gaza strip, and for the first time the occupied territories acted as a nation (Schulz, 1999). Palestinians in the occupied territories lean more toward a political solution then those in exile. They are more likely to accept a Palestinian state in the occupied territories alongside the state of Israel. 


\section{Conclusion}

With respect to the conflict of Israel-Palestine, the root problem is the fight over the Palestine territory. The Arab Palestine who had been displaces now wish to come back to Palestine. This coincidentally, was the very dream of the Jews before 2,000 years of Zionism's emergence. The Declarations of Independence at both sides mark their history and possession of the Palestine territory. Both the subjects have credible political and historical claims with respect to the statehood, yet, there is the absence of a sound case that would deny the other party's right of statehood. Both the parties need to understand the right of the other in order to get their legitimacy acknowledged. Hence, one can find a split picture of the division of Arab Palestinian population in the Israeli literature. The Palestine territory was known as the Holy Land during the Ottoman period. It was also known as Southern Syria, yet the Palestinian Arabs usually called themselves Palestinians with respect to Zionism. The reason of employing the term Filastin as the western Palestine was basically in context of the antiZionist move. Zionism served as a motivation for the Arabs to refer themselves as Palestinians. When the Ottoman Empire collapsed, most of the Arab Palestinians expected Palestine to become a part of Syria, supporting the Arab unity with respect to Arab nationalism. The Arab identity was prioritized over their Palestinian identity. However, this was not so since Arab Palestinians were not clear about the compromises the Syrians had with the Zionists.

\section{References}

As'ad, G. (2001). The Palestinian-Arab Minority in Israel. New York: State University of New York Press.

Baumgarten, B. (2005). The Three Faces/Phases of Palestinian Nationalism, 1948-2005. Journal of Palestine Studies, 34: 25-48.

Benedict, A. (1991). Imagined Communities. New York: Verso.

Donna E. (1997). Refugees into Citizens: Palestinians and the End of the Arab-Israeli Conflict. New York: Council on Foreign Relations. Ernest, G. (1983). Nations and Nationalism. London: Cornell University Press.

Gelvin, J. L. (2009). Arab Nationalism: Has a New Framework Emerged? International Journal of Middle East Studies, 41(01): 10.

Harkabi, Y. (1990). Arab Attitudes to Israel. New York: Hart Publishing Company. New York: Cambridge University Press.

Kaldor, M., Macginty, R., \& Wallenstein, P. (2007). End of Award Report for: The Political Economy of the Israeli-Palestinian and Indo-Pak Peace Processes, 13-25.

Khalidi, R. (2010). Palestinian identity: the construction of modern national consciousness. New York: Columbia University Press.

Khalidi, W. (2006). All That Remains: The Palestinian Villages Occupied and Depopulated by Israel in 1948. Institute for Palestine Studies. November: Institute for Palestine Studies. 
Kimmerling, B. (1999). Religion, Nationalism, and Democracy in Israel. Constellations, 6 (3): 339-363. Leighton, M. (2008). Middleman in the Middle East: America's Flawed Approach to the Peace Process. Orbis, 52 (3): 391-402.

Mishal, A., Shaul, S. (2000). The Palestinian Hamas: Vision, Violence, and Coexitence. New York: Columbia University Press.

Morris, B. (2004). The Birth of the Palestinian Refugee Problem Revisited (p. 219). Cambridge: Cambridge University Press.

Murakami, M. (1994). Water for peace master plan of the Jordan river system. Desalination, 98 (1-3): 459-469.

Muslih, M. (1990). Towards Coexistence: An Analysis of the Resolutions of the Palestine National Council. Journal of Palestine Studies, 19 (4): 7-23.

Onuf, H. (2005). The Three Faces/Phases of Palestinian Nationalism. 1948-2005, XXXIV (4): 2548.

Reuveny, R. (2003). Fundamentalist colonialism: the geopolitics of Israeli- Palestinian conflict. Political Geography, 22 (4): 347-380.

Schulz, H. S. (1999). The Reconstruction of Palestinian Nationalism. New York: Manchester University Press.

Xypolia, I. (2011). Cypriot Muslims among Ottomans, Turks and British. Bogazici Journal, 25(2): $109-120$.

\section{Copyrights}

Copyright for this article is retained by the author(s), with first publication rights granted to the journal.

This is an open-access article distributed under the terms and conditions of the Creative Commons Attribution license (http://creativecommons.org/licenses/by/4.0/). 